\title{
I Want to Tell You a Story: How Narrative Water Ethics Contributes to Re-theorizing Water Politics
}

\author{
Simon P. Meisch 1,2 \\ 1 Institute for Advanced Sustainability Studies (IASS), Berliner Str. 30, 14467 Potsdam, Germany; \\ simon.meisch@iass-potsdam.de; Tel.: +49-331-28822-491 \\ 2 International Centre for Ethics in the Sciences and Humanities (IZEW), University of Tuebingen, \\ Wilhelmstr. 19, 72074 Tuebingen, Germany
}

Received: 2 January 2019; Accepted: 25 March 2019; Published: 27 March 2019

\begin{abstract}
This paper explores potential contributions of narrative ethics to the re-theorization of the political in water governance, particularly seeking to rectify concerns regarding when water is excluded from cultural contexts and issues of power and dominance are ignored. Against this background, this paper argues for a re-theorization of the political in water governance, understood as the way in which diverse ideas about possible and desirable human-water relationships and just configurations for their institutionalization are negotiated in society. Theorization is conceived as the concretization of reality rather than its abstraction. Narrative ethics deals with the narrative structure of moral action and the significance of narrations for moral action. It occupies a middle ground and mediates between descriptive ethics that describe moral practices, and prescriptive ethics that substantiate binding norms. A distinguishing feature is its focus on people's experiences and their praxis. Narrative water ethics is thus able to recognize the multitude of real and possible human-water relationships, to grasp people's entanglement in their water stories, to examine moral issues in their cultural contexts, and, finally, to develop locally adapted notions of good water governance.
\end{abstract}

Keywords: water ethics; narrative ethics; water justice; orientation knowledge; water governance

\section{Introduction}

This paper explores the ways in which ethical engagement with narratives-i.e., the narrative structure of human-water relationships and the significance of narratives for understanding these relationships_can help us to better grasp the genuinely political in water and overcome existing reductionist forms of water governance.

\subsection{Water Governance and the Political}

Water governance is an ambivalent concept. In a way, there cannot be no water governance if governance implies those social mechanisms by which collective decisions about water are made and institutionally implemented. In this sense, even abstaining from collectively addressing a problem area (such as water) is already a governance decision [1]. Hence, as an analytical category, the governance perspective asks whether and how institutions are able to deal with the tasks assigned to them [2-5]. Academic and political discourses often link this perspective to the search for good water governance [6-9]. In a historical perspective, the concept of governance has been contrasted with that of management $[6,9,10]$. Here, the latter is regarded as the prototype of steering and planning by state bureaucracies, whose projects, including large infrastructure projects such as dams, canals or sewage systems, were more often than not implemented top-down, in complete disregard of local conditions [10]. Governance, by contrast, was introduced as a broadening of perspective with regard to scales, sectors, the actors involved in political processes, and policy networks [5]. As opposed to water 
management, which aimed for efficiency, water governance represented the search for legitimacy $[9,11]$. Meanwhile, the governance approach came under criticism because existing forms of water governance did not lead to the anticipated or promised socially just and ecologically tolerable solutions $[10,12-17]$. In addition, conceptions of good governance are based on particular notions of the (morally) Good that often hide behind a technocratic world view and are hardly ever the subject of ethical reflection or public discussion [6,11,18-20].

In contrast, other concepts have been suggested that stress the social nature of water, such as the hydrosocial cycle, socio-natures or waterscapes [17,21-31]. They emphasize the manifold cultural references to and ontological understandings of water and argue for a shift towards the political in water, a dimension marginalized in current forms of water governance. Consequently, this dimension needs to be made visible and productive in order to contribute to the development of just policies and political institutions [20,32-36]. This paper follows the notion of 'the political' that Eric Swyngedouw characterizes as the "contested public terrain where different imaginings of possible socio-ecological orders compete over the symbolic and material institutionalization of these visions. Indeed, the terrain of struggle over political-ecological futures-a terrain that makes visible and perceptible the heterogeneous views and desires that cut through the social body-and how to achieve this is precisely what constitutes the terrain of 'the political'." [37]. So, a key claim of this paper is that the question of the political in water governance is not about a re-politicization of a previously apolitical field, but rather about consistently confronting the always present political and searching for the public dispute over which present and future water worlds we want to share $[11,17,32,37]$. At this level of abstraction, the paper does not yet have to deal with specific understandings of the political, e.g., agonism vs. antagonism [38].

\subsection{Re-theorizing the Political with Narrative Ethics}

The approach to re-theorizing the political in water governance put forward in this paper draws on ancient Greek understandings of theory. The verb theôrein means 'to look at,' 'to observe,' 'to see,' or 'to contemplate' [39-41]. Thus, in contrast to its use in modern science, the noun theôria refers to the observation, spectatorship, and contemplation of reality-and not its abstraction [40,42]. From early on, this definition provoked debates about the conceptual relationship between theory and practice (praxis). In this reading, theory reflects social practice, but is not itself this practice. In re-theorizing the political in water governance, the paper concerns itself not with abstraction, but with concretization by linking concepts of water governance with life-worlds. In so doing, it introduces 'narrative ethics', which combines the morally important category of experience with reflected action and identity formation $[43,44]$. This paper understands ethics as the academic discipline that reflects on morals, i.e., the practiced beliefs about what people or groups consider desirable or what they feel obliged to do. Thus, morals are the subject area of ethics [45-47]. Narrative ethics addresses hermeneutical questions of moral practices. It draws on many intellectual sources, including Charles Taylor, Paul Ricœur, Martha Nussbaum, and Judith Butler [43,48]. In this paper, I refer to the version of narrative ethics developed by Dietmar Mieth [43,44,48] and influenced by him, Hille Haker [46,47,49], Marcus Düwell [50], Regina Ammicht-Quinn [51,52], and Walter Lesch [53].

Within the academic dispute on what constitutes an appropriate reflection on questions of the good life and the right actions, narrative ethics positions itself in a specific-mediating-way in-between prescriptive forms of normative ethics on the one hand and thick descriptions of the cultural and social sciences on the other $[46,53,54]$ : "Narrative ethics is not descriptive ethics because it is a component of the value-oriented debate about the good life, and it is not prescriptive ethics either because it does not itself become a discourse of reasoning, even though it provides the hermeneutic framework conditions for the normative question of moral reasoning, provided that this is related to historical situations and transcends the formal discourse of reasoning." [47].

With a narrative water ethics, this paper provides a conceptual lens to make visible and contemplate the political in water governance. It adds a crucial dimension to water governance: 
reflecting and settling upon the aims of contextualized and situated governance approaches [2,55]. So, narrative water ethics aims to improve actual water practices, which first of all need to acknowledge that there are 'multiple ontologies of water', as Julian Yates and colleagues point out [28]. In doing so, narrative water ethics draws on the potential of narratives "in creating an alternative space for ecological imagination" [56,57]. As such, it is well suited to better observe, concretize and contemplate certain aspects of the political in water governance, such as context, agency, contestation or values and norms. By dealing with stories, i.e., the narrative structuring of experiences and actions, narrative water ethics contributes critically and constructively to re-theorizing the political in water. Its critical perspective problematizes existing moral systems and storytelling itself, while its constructive perspective aims to provide orientation for water action and to influence the debate on historically situated issues about the good life and the right action $[46,47,56,58]$. So, this paper argues for the potentials of an analytical perspective and does not present empirical results. It proposes an approach or method with a view to achieving more reflective water practices, rather than a specific moral approach to how people should act with regard to their waters $[43,59]$. Thus, the paper's other key claim is that engaging with the narrative structure of human-water relationships enhances debates on the good life and increases the reflexivity of people's deliberations on possible and desirable water futures and policies $[46,55]$.

This paper first addresses aspects of the current critique of water governance and, in this context, explains why the re-theorization of the political in water is necessary (Section 2). It then presents narrative ethics, as a promising way to recapture the political aspects of water (Section 3). Finally, it discusses various facets of what this re-theorization implies for water governance in terms of both contemplation and concretization (Section 4).

\section{Reductionist Water Governance}

The desideratum to re-theorize the political in water governance originates from descriptions of a dual deficit. First, since Rene Descartes, the project of modernity has increasingly produced governance approaches that build on and reinforce the separation of nature and culture and, in this context, the exclusion and objectification of water. As a result, water became an issue that needed to be-and could be-mastered by technoscientific means and was thus removed from its social and cultural contexts. This led to injustices through the deprivation of rights and the destruction of the environment [12,16,60-63]. Second, governance approaches tended to focus on issues of action coordination and to a lesser degree on underlying political problems, related values and norms and affected actors $[3,4,55,64,65]$. Ultimately, this led to the de-politicization of water and its handling by technoscientific and managerial means-even though water is a paradigmatic wicked problem that is imbricated with social controversy and needs constant political renegotiations of potential solution paths $[15,66,67]$.

\subsection{Excluding Water}

Researchers from the critical social sciences and the humanities have consistently drawn attention to the dialectical relationships of people and societies to their waters [14,21-23,29,42,68-71]. On this reading, water is appropriated symbolically and culturally in various ways and thus acquires its meaning through the social and cultural circumstances in which it performs its roles while simultaneously shaping the identities of the people who interact with it. In this respect, water is "a product of historically sedimented social actions, institutions, struggles and discourses, which in turn help shape the social relations though which it is produced and enacted" [12]. Corresponding research is interested in hydrosocial cycles, i.e., the "socio-natural process[es] by which water and society make and remake each other over space and time" [22].

Since early modernity, however, reductionist notions of water have prevailed. They tend to reduce water, in all its rich cultural and social manifestations to a single universal substance, represented by the molecule $\mathrm{H}_{2} \mathrm{O}$, which circulates in the water cycle and whose graphic representations do not 
typically feature humans or societies. This truncated conceptual perspective on water was described by Jamie Linton as the main characteristic of 'modern water' [21]. European Modernity turned water into the alien Other, an object that could be conceptually excluded from and mastered by Culture [16,71]. Capitalist appropriation reduced it to a resource that was supposed to float freely in order to maintain global markets [72-75]. Eventually, the technoscientific 'hydraulic mission' turned water into a technical matter beyond all politics, as Ronaldo Munck explains: "Across the water sector there is an abiding belief in science, technology, and engineering as drivers of progress. One need only add the right mix of private and state investment and generate the right attitude among the population for success to be achieved" [10]. These conceptions of water have repeatedly been criticized and dismissed. For instance, Hartmut Böhme strongly pleads against the suppression of the religious, philosophical, aesthetic and phantasmatic dimensions of water. In his view, the mythopoetic history of water has not been overcome by excluding it from what is privileged as rational knowledge within the water sector. Detaching water from its cultural embedding ultimately made way for blind and ruthless exploitation, water waste and environmental destruction [16]. The many current environmental devastations and social injustices show that the technoscientific use of water by no means produces morally and politically neutral water.

Social science studies have consistently shown that even though water has been made a contextless resource, it has not become value-free $[21,22,26,28,68,72-74,76]$. This focus emerges clearly from the distinction introduced by Karen Bakker who distinguishes between $\mathrm{H}_{2} \mathrm{O}$ and water: "Whereas $\mathrm{H}_{2} \mathrm{O}$ circulates through the hydrological cycle, water as a resource circulates through the hydrosocial cycle-a complex network of pipes, water law, meters, quality standards, garden hoses, consumers, leaking taps, as well as rain-fall, evaporation, and runoff" [74]. The normativities associated with water are built into and effective in these systems. While this comes as no surprise to scholars in the social sciences and humanities, it has become increasingly obscured in the thinking of many in the water sector $[10,17,76]$. Precisely because "every political project embodies a process of socio-environmental transformation and every socio-environmental project reflects and materializes a particular political vision," Eric Swyngedouw reminds us, "water is inherently political, and therefore contentious, and subject to all manner of tensions, conflicts, and social struggles over its appropriation, transformation, and distribution, with socio-ecologically unevenly partitioned consequences" [77]. This implies that the political in water governance must be made visible and reflected in terms of its power and normative structures.

\subsection{The Problem of Water Governance}

As an analytical category, governance was distinguished from government [3,12,64,65]. The plausibility of this shift rested on the partial failure of earlier models promoting political steering by the state. With regard to water governance, Munck refers to the era of developmentalism [7], which assumed that there was a single path to modernity that all countries would have to follow and which mainly focused on large infrastructure projects. For many reasons, this model reached the limits of its capacities, but also failed to meet its normative standards (e.g., marginalization, corruption, environmental destruction). In contrast, the governance approach provided an alternative model that promised to do justice to the complexities of political realities and to take further actors and scales into account when coordinating political action $[78,79]$. Political rule was no longer just steering, but rather negotiating in networks and political structures that could also emerge spontaneously according to the requirements of the problem at hand [10,65].

Consequently, governance approaches focused on action coordination, regulatory structures, and their impact on actors. Yet, by doing so, they appeared to sideline insights of the sociology of domination and thus constitutive elements of the political: the contentious definition of political problems, the normative orientation and political action of the actors involved as well as the explicit debate on political goals $[4,5,55,80,81]$. Furthermore, governance approaches remained ambivalent regarding their normative foundations. For instance, Renate Mayntz points to a 'common good bias', 
i.e., the tacit assumption that governance promotes the common good $[2,4,55]$. Whether or not this is the case, however, is an empirical question and cannot simply be presumed. In addition, Ellen Immergut elaborated on the extent to which different governance modes rest on specific normative foundations. They are based on preconditions that have political consequences and are hence never merely neutral political instruments [82]. Concepts such as 'good water governance' or 'meta-governance of water' are aware of this ethical dilemma by proposing either evaluative criteria or a further steering structure $[6,8]$. However, in this way they simply shift the burden of justification to values that come from specific social contexts and would in turn need to be justified ethically, or to a forum that would then have to be able to resolve political disputes over problem descriptions, values and norms, and the distribution of power. This problem became particularly visible in good water governance approaches which, more often than not, left underlying understandings of the morally Good implicit $[6,11]$. In addition, organizations such as the World Bank or policy programs such as Integrated Water Resources Management or the Water Energy Food Security Nexus promoted specific Western ideas of the Good behind a technocratic veil $[6,10,11,83]$. So, what should be controversial questions about values, norms and political aims takes the guise of mere questions of management, often combined with a constructed urgency to act quickly in order to avert various water crises [18,27,62]. This implies that water governance approaches need a reflective dimension that is able to meet moral challenges that are part and parcel of the political.

\subsection{The Wicked Problem of Water}

In the early 1990s, neoliberal water governance emerged fusing the notion of modern water with the deliberate disregard of issues of power and dominance in particularly extreme ways $[12,26,78,79]$. While the first reduced water to a contextless resource in the hands of technocrats who supplied it to capitalist exploitation, the latter left the search for political goals to self-organization processes of which it could not really say how they could lead to just solutions, but which at least knew no democratically legitimized actor of political steering that would set moral limits to market forces. Both trends are symptomatic of a broader de-politicization of public concerns and of the crises of the sciences faced with these concerns. This is particularly problematic as the search for morally acceptable paths of shaping water-human relationships deals with 'wicked problems' [61,66,67], i.e., complex and unique situations for which there is neither a simple nor a single (correct) solution. Because of the complexities and cognitive uncertainties of wicked problems, social solutions cannot be judged by the standards of true or untrue, but only of better or worse. In this sense, solutions to wicked problems are always of a political nature because they are intimately related questions of how water-human relationships in a certain location should and can be shaped at a certain time-according to affected citizens' notions of the good life and the right actions in relation to their water. Due to dynamics within hydrosocial cycles or waterscapes, these relationships will never be finally settled, but must always be socially renegotiated and ethically justified.

In order to respond to wicked problems, waiting for scientific consensus is neither necessary, possible (due to complexities and uncertainties), nor desirable (in political terms) [61,67]. The technological side of things is often not the obstacle; sufficient knowledge and experience exists on how to build water infrastructures $[15,84]$. However, there are often different legitimate perspectives on a problem and conflicting ideas about possible futures. According to Alice Benessia and colleagues, reducing water to a mere technoscientific issue raises serious democratic challenges because the underlying logic leads to the search for solutions "within the shared and implicit cultural frame of modernity, according to which waiting for the unequivocal and certain opinion of science is a fundamental requirement for legitimate and responsible action. This means giving up our agency as members of civil society and, most importantly, it implies a continuous procrastination, because the future is, in fact, irreducibly indeterminate and intrinsically complex" [61].

Against this background, it becomes evident why the de-politicization of water has become such a problem. The ability to grapple with the political in water contexts is a prerequisite for political 
action in the first place $[15,37,57,66,85]$. These contexts are ambivalent and resistant, which implies that they are characterized by uncertain facts, diverse worldviews, and controversial values and norms. Thus, they cannot be reduced to simple formulas, which in turn would serve as the basis for undisputed water governance. So, citizens need to understand how they are entangled with their water at certain times and in certain places (i.e., context). They can gain this understanding by engaging with their own stories and symbolic orders that deal with the historical contingencies of their relationship to water. They can also become aware that these relationships can be shaped in dispute and that the future is thus open. According to Swyngedouw, the re-politicization of water means that "it is important to foreground division and exclusion, and to emphasize 'the political act' and a fidelity to a political truth procedure that necessitates taking sides while aspiring to universalization. The latter refers to a politicizing process whereby everybody is invited in (although by no means all will accept the invitation)" [37]. The re-politicization of water raises the question of political power, with a view to the transformation of real orders and the search for new symbolic orders. These new orders foster meaningful political actions and social institutions to support them [37,38]. This implies that, alongside scientific knowledge, other forms of knowledge can also become relevant for policy-making $[61,86]$. However, this cannot be about putting "science side-by-side with so-called 'local', 'traditional', or 'folk' knowledge in an implicitly hierarchical interdisciplinary pool [ ... ], but, instead, to confront the more ambitious challenge of encouraging the emergence of new kinds of hybrid knowledge and practice-a synthesis beyond the individual parts-through extended participatory processes" (italics in original) [61].

\section{Narrative Water Ethics}

The theoretical re-conception of the political in water governance requires an understanding of the spatial and temporal dimensions of water, i.e., its context $[15,17]$. This includes (but is not limited to) the abilities to acknowledge people's experiences with their waters (beyond $\mathrm{H}_{2} \mathrm{O}$ ), to perceive the plurality of different (contentious) cultural perspectives on water and the values and norms associated with it, and, finally, to argue or quarrel about these values and norms. Academic ethics generally regards the systematic exploration of values and norms, as expressed in different moral systems, and the orientation towards reasoned action as its central tasks $[36,54,87]$. This also applies to water ethics [19,88-90]. In narrative ethics, an approach within application-oriented ethics comes into focus that explicitly regards itself as contextual ethics and claims a place between the exact description of moral contexts of action and the prescription of rules of action. Narrative ethics deals with the narrative structure of actions and the significance of narratives for actions $[47,54]$.

\subsection{Ethics and Morals}

This paper distinguishes between ethics and morals. The academic literature uses both terms in different ways. This is not really a problem as their scope and meaning have repeatedly changed in the history of philosophy. For the purpose of this paper, it is not necessary to retrace their complex and ambivalent genealogy [36,87]. It is important, though, that it becomes clear how they will be used subsequently. In line with current moral-philosophical literature [36,54,87], I understand morals as the entirety of convictions held by individuals or communities about which aims are desirable ('the good life') or how they ought to act ('right actions'). Consequently, morals relate to the evaluation of actions by asking how we can live truly successful lives or what we are obligated to do [45,91,92]. As attitudes, motives, intuitions, norms, or institutions relate to actions in one way or another, they are subject to morals too. From morals, I distinguish ethics understood as the systematic reflection on the reasons why we ought to act in a particular way. Generally speaking, morals do not question their own justification; rather, they are simply lived. In contrast, ethics asks for reasons of validity. In daily life, people do this all the time. Academic ethics moves beyond this lifeworld reflection in a more systematic and methodical way [45-47]. 


\subsection{The Ethical Relevance of Narrations}

Narrative ethics argues that forms of ethics focusing on discursivity and argumentation remain incomplete and cannot do justice to the complexities of moral questions within social contexts. As such, it does not reject normative ethics' search for claims to the validity of the reasons for our actions $[47,54]$. Yet narrative ethics insists that this alone cannot be enough, because this kind of ethical reflection lacks the "historical and life-world depth of focus" [46]—or, in other words, context. Thus, narrative ethics insists that narration is a necessary form of addressing moral questions.

Narratives refer to people's experiences $[43,47,53,54]$. However, they do not simply depict these experiences in a quasi-photorealistic way, but rather create or produce them in the first place. According to Haker, events or the experienced in general become experience by being reflexively reworked. In this respect, narrations play a central role by not only representing and articulating events, but also ordering and interpreting them through their structure. Experiences are not simply shaped by narrations; they also become accessible through them. Narrations configure events and event elements into units of significance that are directed at someone and designed to convey meaning [46]. Thus, narrations are a medium for jointly exploring reality and making it communicatively available. In this vein, narrations reflect systems of values and norms, but are also a medium in which moral conflicts are staged $[46,47,93,94]$. They tell what is actually the case in a certain social context, and in what way moral conflicts are treated and, perhaps, resolved. Since such narratives also deal with good or right actions in social spaces, they are constitutive for the formation of the political $[93,95]$. As such, narratives deal with and lend legitimacy to public action $[56,57,94]$.

In this respect, it becomes clear that daily actions are always narratively structured in that they are geared towards goals, have a temporal structure, refer to action contexts, and involve other actors $[46,47,93,94]$ : "actions and attitudes only become significant by means of their connection to the biographies or life histories that, in turn, remain incomprehensible without their historical, cultural and social contexts. Both dimensions can thus be viewed as 'con-texts' for the quasi-text of the action itself" [47]. Actions thus reveal what a person or a group wants to be and how their intentions and actions have been shaped (or disciplined) by these contexts. In this vein, actors are always 'relatively autonomous' or as Haker explains: "Speaking of a narrative identity means reflecting upon the reflexive structure of identity and the entanglement of the self in stories. What is impossible, then, is to regard the moral self as an atomistic, individualistic, sovereign self-although it is not possible to rule out autonomy altogether." [47].

Re-theorizing the political involves the perception of various morally charged perspectives on the world and the recognition and handling of emerging value conflicts. For an ethics that intends to confront precisely these tasks, engagement with narrativity is crucial for three reasons [46]. First, ethics must recognize that and to what extent moral practice is linked to the experiences of people acting in specific situations. Ethics refers to moral practice by reflecting on and analyzing the actions of people and social institutions: "Theory and practice are necessarily intertwined in ethics, and thus a reflection on the narrative structure of practice is inevitable" (own translation) [46]. Second, ethics has to deal with the fragile status of judging [44,46,59], because not only moral action needs ethical justification, but also ethical judgment, insofar as it is itself an action. Dealing with conflicts of norms and values in contested contexts is a complex matter of judging individual action(s) as well as the actor(s) involved [46,47,93]. Moral judgments are not simply argumentative in nature, referring to the good life or the right actions; they are also interpretations of action situations. Thus, they are prone to error in two respects: they can draw false normative conclusions or misinterpret a context of action. Narrative ethics thus raises awareness that moral judgements make interpretations about both individual actions and the contexts of action: Such judgements refer to the subjects of action, whose motives and backgrounds they can never know completely, and to situations that need to be interpreted, but could always be interpreted differently. Third, ethical theories come from somewhere, i.e., they have a pedigree in space and time that needs to be recognized so that it does not become a blind spot of ethical judgement. They have to be self-critical about their own implicit narratives. 
In summary, for the examination of narrativity, this implies that stories can change according to context and perspective, but above all in the light of new experiences. Hence, both the generation of meaning and the awareness of the contingency of this meaning produced qua narration are crucial for understanding social contexts and the contested notions of the good life and the right actions.

\subsection{Fictional Narratives}

Works of fiction represent a particular kind of narrative $[46,47,54,96]$. Like real-life narratives, they represent events and experiences and thereby constitute them. As compositions, both kinds of narrations also have a rhetorical intention. However, they differ insofar as lifeworld narratives are (mainly) committed to reality, while in fictional narratives-from stories, radio plays and movies to modern forms of serial narrations provided by streaming services-actors, contexts, and moral conflicts are a function of aesthetics. As works of art, they enjoy artistic freedom and are not obliged to be a truthful representation of reality. At the same time, they have the potential, for example through their narrative strategies, to depict the complexities of reality and the plurality of perspectives and voices more appropriately than reports, or to unsettle their recipients' perspectives on reality and encourage criticism. With regard to fictional stories, narrative ethics questions both the moral conflicts at the narrative level and how this fictional reality is shaped by narration. In this sense, fictions always portray a different reality (in a format designed to be appealing), while repeatedly throwing recipients back on their role as interpretive observers of that reality. In doing so, narrations can also intensify the view of recipients for different readings of their own lifeworld [96,97]. Examples of fictional water narratives will be discussed below.

\subsection{Constituting Moral Judgements in Contexts}

It is evident from the preceding that ethics, as the critical analysis of morals and the constitution of moral judgements, cannot be reduced to a deductive sequence from principle to norm to judgement $[98,99]$. Mieth emphasizes that although moral norms can be subsumed under an ethical principle, they cannot be derived directly from this principle. In the academic literature, there is often the misconception that moral judgements can be deduced from a universal criterion. Yet, for Mieth, formulating judgments about how we should act always involves the ability to recognize and explain existing norms and values and relate them to one another, the perception and interpretation of action contexts, as well as experience and a combinatoric sense that brings together statements with normative and evaluative character and a descriptive character in a moral judgment. For this purpose, he proposes a conductive and iterative method that includes the following components $[44,98]$ :

- Hermeneutics of preconceptions: When dealing with moral questions, we never take a 'view from nowhere'; in other words, we all have our preconceptions and prejudices. Yet, while this is inevitable, we can learn to perceive these biases and reduce their influence to a reflected and tolerable level when dealing with a contested situation.

- Knowledge of the relevant facts: When describing and reconstructing politically controversial situations, there are always statements that either require empirical verification (or falsification) or could be verified (or falsified).

- Knowledge of ethically relevant meanings and corresponding valuation judgments: Within scientific knowledge (production) and lifeworld discourses there are evaluative and prescriptive statements that can be reconstructed and whose justification has to be examined.

- Rationalization of alternatives: Potential alternative judgements about the relevance and preference of knowledge and expertise as well as meanings, value orientations and obligations need to be brought into the best possible state of argumentation.

- Weighing up priorities: Seeking possible ethically sound and jointly acceptable courses of action requires the development of criteria against which priorities can be weighed. This should be 
seen as an iterative process, because further values and new facts can lead to new relevance and different judgements.

This conductive method builds on the practical syllogism that combines empirical-descriptive and prescriptive premises in the constitution of moral judgements [44,54,98,100-102]. At the same time, it highlights the fact that the analysis of narratives always has to do with moral judgements and thus with the intimate relationship between described facts and events and the values and norms that give these facts and events their meaning and relevance. So when confronting controversial political situations, we also have to be aware of what is controversial in the first place: the factual basis, the value basis, or the ways they are combined. Against this background, narrative ethics can be considered an analytical tool, because it pays attention to what we encounter in controversial political situations, and at the same time provides a constructive method for identifying ethically reflected and collectively responsible paths of action [46,93-97].

\section{Narrative Water Ethics and the Re-Theorization of the Political}

The function of narrative water ethics can be illustrated by the sentence: 'I want to tell you a story!' A speaker-subject (individual, collective) wishes to communicate and asks or demands the attention of a listener-subject. The latter is confronted with the narrator's (counter-)story, i.e., he or she needs to deal with the narratively composed world of experience of this other subject and behave critically towards it. It is the active confrontation with this Other, whose right to speak is respected, and the search for a joint inter-esse, which according to Hannah Arendt emerges between them and is shared by them [103]. In this sense, narratives draw attention to ethically exposed contexts, encourage discussion with them, and challenge listeners to develop their own attitudes. In particular with regard to socio-natures, narratives are able to express the manifold aspects of emotionally charged human-environment relationships. Beyond that, they have the potential to give a voice to non-human nature and to make its material effectiveness visible and comprehensible [56,58,95,104]. Consequently, speaker- and listener-subjects establish among themselves what is actually the case.

Narrative water ethics thus understood refers to concrete persons, actions, geographies, institutions, as well as value and norm systems and explores how these are all entangled in water stories $[15,16,43]$. In doing so, we would not do justice to the depth of water as a reservoir of cultural meanings if the analysis of these stories were to refer solely to literature, and in particular high literature $[13,16,28,70,71,105]$, as Böhme cautions: “The symbolic use of water has a formative effect in superstition as well as in creation theology, in fountain culture as well as in baptism, in myth and poetry, in adventure novels as well as in the sailor's yarn, in folk-literary traditions as well as meta-poetological narratives, in spontaneous dream images as in artificial water landscapes, in water music as in fairy tales, in temple rituals and horticulture, in magic as in psychoanalysis, in sagas about water monsters as in sacred texts about the dwelling of God in water" (own translation) [16]. Innumerable narrative formats thus deal with water; and often, water and its metaphors structure our ways of thinking in the first place $[42,106,107]$. If we engage with narrative entanglements of people with their waters, we need to become aware of this ontological plurality-in particular, if we aim to make it productive for better water governance [28].

\subsection{Connecting to People's Experiences with Waters}

Narrative water ethics recognizes people's experiences with their waters and their desire to share these experiences. Two examples working with narrative formats and narratives will be highlighted hereafter. One is the project "The Reasons", a format for public storytelling, which was developed by a British research project aimed at bringing citizens of the Fenlands district in Cambridgeshire (England) into conversation about possible shared water landscapes [108]. The Fenlands are partly below sea level and require complex water management (even without the challenge of climate change). The Reasons format is based on a traditional Italian dispute resolution mechanism that resembles a court scene and has formalized roles. This format was adapted to the British context and modified 
to the extent that the focus was no longer on resolving a conflict but on starting a joint thinking process, the result of which was the development of polyphonic narratives and the creation of water as a shared inter-esse. Another example is quantitative story-telling [109]. This is a systematic approach in the tradition of post-normal science that investigates the role of socially constructed ignorance in evidence-based policymaking [110-112]. It focuses on other legitimate narratives besides the traditional scientific perspective and integrating different representations of knowledge for decision-making. For instance, the EU project MAGIC applies this perspective to narratives on future water security [113]. The project succeeds in anticipating possible water futures and in identifying and excluding unrealistic narratives as technoscientific fantasies [109,114,115].

Both projects work in different ways with narratives and the idea that narratives are key to understanding multiple water worlds. Beyond what they have achieved so far, engaging with narrative ethics allows them to systematize emergent moral issues and grasp the normative implications of narratives more consistently. Both projects thus open up public discourse on possible and desirable water futures. On a more fundamental level, narrative water ethics can supplement social analyses by making visible the point of view from which criticism is expressed-be it in the case of unjust narratives of water security in the Water Energy Food Security Nexus [18] or racist symbolizations and institutional configurations of water infrastructures $[10,76]$.

\subsection{Experiencing Otherness and Complexity}

Narrative ethics takes on an additional critical function by providing spaces for experiences of otherness and complexity. Literature is particularly capable of achieving this. In the following, some literary texts will be highlighted as examples. Their selection is contingent and other examples could also be chosen to make the point. Different authors invite us to take alternative views of water and in this vein turn familiar images of political geography on their heads. A well-known example is Roger Deakin's Waterlog (2000), in which he reports on his experiences of swimming through all the British waters and thereby encourages a new perspective on the role of water and water bodies in public life [116]. In The Old Ways (2012), Robert Macfarlane invites us to think about the seas of Northern Europe (the Atlantic Ocean, the Baltic Sea, the North Sea) as land and the land as water. In this way, he is able to reveal centuries-old connections between people, regions, and cultural spaces, which through a land-based political geography were previously marginalized and thus literally vanished from view: "The sea has become the land, in that it is now the usual medium of transit: not a barrier but corridor." [117]. For these people and regions, water is their inter-esse in many ways. Both texts encourage recipients to think in alternatives about and through water and to engage with water's agency.

A more profound reflection on our water worlds today might also begin by dealing with texts from historical eras, which are very alien to us [118]. Stefan Hofer-Krucker Valderrama, for example, deals with a text by the Swiss author Jeremias Gotthelf [119]. As pastor of the village of Lützelflüh, Gotthelf was an eyewitness to the historic flood disaster of 1837 in the Swiss Emmental valley. He deals with his traumatic experiences in "Die Wassernot im Emmental" ("Water Disaster in the Emmental Valley", own translation), which Hofer-Krucker Valderrama describes as a hybrid narrative. This text is particularly interesting because it appears on the surface to be a typical penal theological text in which a Protestant pastor views the floods as punishment for people's sins. Hofer-Krucker Valderrama, however, shows how Gotthelf ingeniously unites and correlates different forms of knowledge that are crucial for the perception, the descriptive, narrative and documenting representation, as well as the interpretation and classification of such an event. In addition to eyewitness accounts, Gotthelf's own observations and biblical references, the text also incorporates geographical knowledge, knowledge of road and bridge construction, and regional myths relating to the natural world, such as the Legend of the Emmen Serpent. The text thus achieves a high degree of complexity and polyphony in that different forms of knowledge interact, overlap, complement and contradict each other. Gotthelf's seemingly simple religious narrative reveals moral fault lines around the appropriate forms of possible, better 
water worlds and their institutional configurations. Traditional views interfere with emerging notions of social and political responsibility for preventing such disasters and mitigating their consequences.

Ancient myths and their persistence into the present day can challenge dominant narratives about water worlds and invite us to engage with experiences of otherness and social distortions in human-water relationships. A particularly appealing example of this is the Dutch water-wolf. This is an animalization, i.e., the description of non-living phenomena such as geographical characteristics using traits assigned to certain animals, in this case the wolf. The geological phenomenon is from the Netherlands and refers "to the tendency of lakes in low lying peaty land, sometimes previously worn-down by men digging peat for fuel, to enlarge or expand by flooding, thus eroding the lake shores, and potentially causing harm to infrastructure or death" [120]. A particular case is the Haarlemmermeer, which today is a polder in the southwest of Amsterdam. Around 1500, poorly constructed dikes and the extraction of peat led to four lakes at this location being combined into one-the Haarlemmermeer. At the time, it was the largest lake in the Netherlands. Its subsequent expansion resulted in the destruction of several villages and threatened to flood the cities of Leiden and Amsterdam, prompting the Dutch government to undertake to drain the lake in the mid-nineteenth century.

Figure 1 shows the battle of the Dutch lion against the frightening water-wolf. Draining the lake finally eliminated the hazards of flooding and created new land in the densely populated Netherlands. However, comparable to the extinction of the wolf in order to 'free' Europe's landscapes for large-scale sheep farming, the extinction of the water-wolf is a narrative of the victory of industrial man over water, as is reported, for instance, on the website of Cruquius Museum dedicated to the draining of the Haarlemmermeer: It "tells about the age-old Dutch battle against the water. The reclamation of Haarlemmermeer by means of steam power marked the breakthrough of the Industrial Revolution in the Netherlands" [121]. Meanwhile, this narrative conceals the considerable human suffering and strife caused by the fact that the people who lived off and with water (fishermen, traders, ferrymen) lost their livelihoods. The story of the water-wolf is thus a story told by victors. Against this backdrop, the narrative confronts us with a problematic narrative agency, while familiarizing us with moral complexities, as changes in hydrosocial cycles are politically and morally never neutral [23]. In this respect, the water-wolf invites us on the content level, to confront complex socio-ethical conflicts and on the formal level, to engage with the narratives of industrial modernity. The fact that Schiphol Airport, Europe's third busiest airport, is located in Haarlemmermeer adds a special note to this example. In the face of rising sea levels due to climate change, the Netherlands are once again facing an upheaval of its hydrosocial cycles. Just as the real wolf is returning to Central Europe, the water-wolf might also be making a comeback. Thus, an old myth might be resurrected-and thereby trigger an old political debate about desirable water worlds.

The narratives that are constitutive for water research and determine how water is appropriately studied constitute another interesting and significant object for narrative water ethics. The emergence of 'modern water' [21,22] can be regarded as such an example in case. Jeremy Schmidt contradicts Linton's narrative tracing the emergence of modern water from a specific historical U.S. context, which thus establishes a specific problem description and research agenda [122-124]. Schmidt, in contrast, puts forward the notion of 'normal water', i.e., "a program for bringing water's social and evolutionary possibilities into the service of liberal forms of life" [123]. Against the background of this controversy, narrative water ethics can take on different perspectives. It could examine how both authors first construct the moral situation of their respective narratives, each of which deals with how people organize relationships with their water. Second, the question arises as to how these narratives developed into reference points for researchers that contain statements about good and correct water research and thus define inclusion and exclusion relationships. Third, these stories produce moral claims for alternative water policies. Finally, water ethics may have a mediating role, as it seems that both authors share the view of water's social embedding, despite differences in the interpretation of the historical situation. This case reveals that and how narrative ethics is also an ethics of science (cf. also the examples in Section 4.1). 


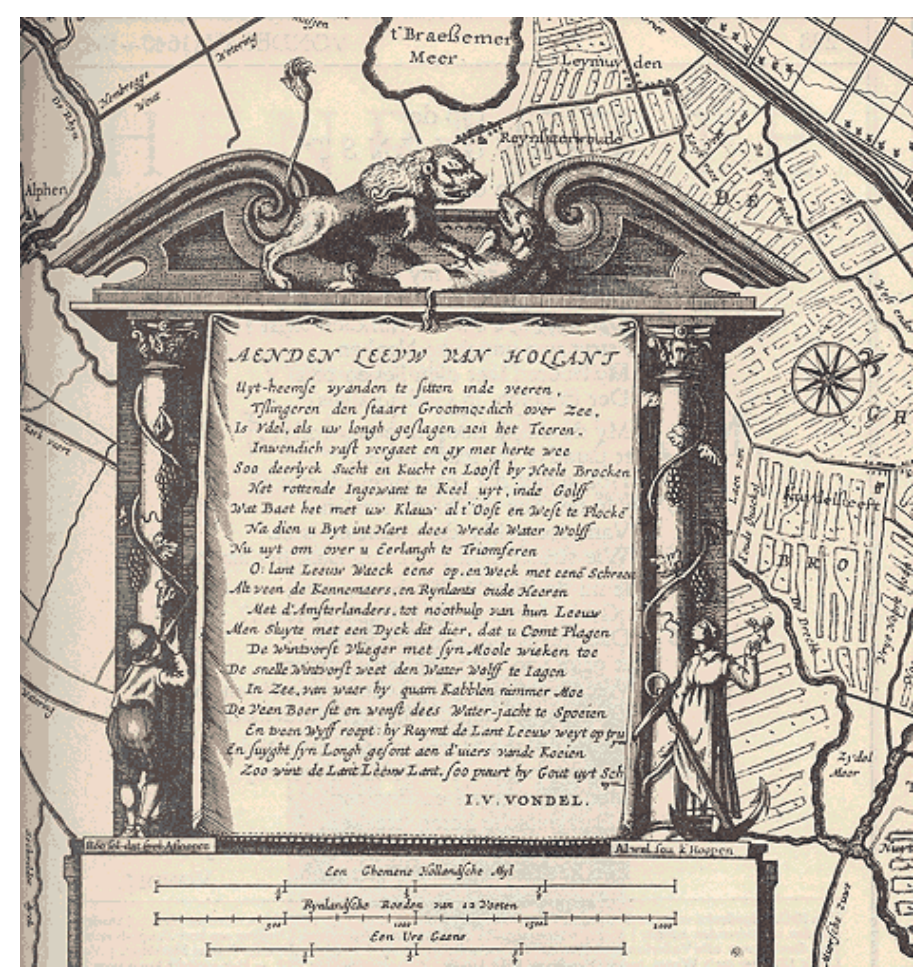

Figure 1. The battle of the Dutch lion against the water-wolf as an allegory of the battle of the Dutch against the water [120].

The previous reflections explored from a critical perspective the contributions of narrative ethics to substantiating the political in water. It has been illustrated that narratives (a) draw attention to conflicts of values and norms and invite recipients to take a stand; (b) create space for experiences of otherness and contrast that create an awareness that reality could always be different and that a multitude of legitimate other (non-human) perspectives exists; and (c) can be open to conflicting perspectives and forms of knowledge. Narrative ethics can thus sensitize us to water contexts and the ways in which people are entangled in and motivated by their water histories [56,118]. However, the considerations so far are not intended to convey the impression that the 'moral of history' could be directly translated into political practice $[16,28,118]$. This would probably be just as naïve and unrealistic as the idea that narratives could be used to steer politics to a precise point [94]. Rather, it is about developing competences, attitudes and critical perspectives.

\subsection{Guiding Water Governance}

Inspired by the conductive method, narrative ethics intends to instruct social action that captures multiple worldviews and permits contextually specific political courses of action. As such, narrative water ethics can substantially contribute to Bakker's recommendation for good water governance [125]. She suggests that local policy-makers should decide for themselves what good water governance means for their communities and make this process of setting criteria as inclusive and democratic as possible. She thus proposes the creation of contextually adapted criteria, which should emerge from an inclusive process and subsequently orient the actions of political actors. A key feature of this proposal is that it explicitly addresses the responsibility of the political system. The conductive method provides a heuristic to the process proposed by Bakker, for it helps municipalities and communities to identify the facts, values and norms - and the interdependencies between them-that are relevant to their water relations. Narrative ethics listens to and recognizes the stories of people's entanglements with their water and helps them to identify their own relevance criteria for water governance. In this regard, narrative water ethics promotes a 'value-reflexive governance of water'. In contrast to good governance, this perspective develops the awareness of which and whose values 
are actually in the political discourse or which ones are missing; what particular values mean and how this meaning changes when these values come into contact with other values; and, finally, how this value hermeneutics can be translated into political courses of action within the framework of justice $[11,19,32]$. Since value debates are low-threshold entries into ethical debates and inherently associated with experiences that have led to these values, such water governance invites everyone to participate in the debate [37]. These locally adapted understandings of water governance are far better equipped to make the political in water governance visible and concrete, i.e., by inviting everyone to disagree about the multitude of legitimate perspectives on possible and desirable water futures. In this understanding, there is a thin universal ethical claim behind this approach [126].

\section{Grasping the Political in Water Governance}

This paper elaborated how narrative water ethics contributes to re-theorizing the political in water governance by making the inherent political visible, concrete and productive for social deliberations. It advanced two claims. First, the question of the political in water governance is not about a re-politicization of a previously apolitical field, but rather about consistently confronting the always present political and searching for public debates over present and future water worlds. Second, engaging with the narrative structure of human-water relationships enhances these debates and supports the reflexivity of people's deliberations on possible and desirable water futures. To this end, the paper suggested using the potential of narrative ethics for water governance. In particular, the paper was concerned with recognizing water stories as the structured experience of people with their own waters and grasping their content (interpretations of reality, norms, and value systems). These stories have the ability to represent complex situations and contradictions by integrating and composing different worldviews. This results in hybridized forms of knowledge that enable people to reflect on their relationship to their waters and act together to create their water worlds.

This paper presented a conceptual proposal whose potentials need to be developed in different directions. One might ask how narrative water ethics extends existing research questions and political options for action or opens up new ones. The approach also needs to be further elaborated with regard to the question of how it relates to conceptions of the political [38]. Probably, an approach emphasizing the value of plural perspectives on water worlds is closer to agonistic than to antagonistic conceptions. Another theoretical challenge relates to the subjects narrative ethics envisages, for each theory has an implicit understanding of actors and appropriate actions [65,79]. In this respect, McNay accuses radical democratic or narrative political theories of a "socially weightless mode of theorizing that forecloses a developed account of social power" and of ignoring "patterns and particularities of the lived reality of oppression" [127]. This criticism goes deep. However, narrative ethics is well aware of this problem and can make it its task to mediate in this respect [128]. There are ethical challenges, too, because narrative ethics is an explicitly contextual approach. The ethical questions dealt with in this context would have to be related to universal debates such as the human right to water or water justice $[12,32,126]$. In this respect, there are mutual reservations between relativistic and universalistic ethical approaches [129-131]. Narrative ethics is able to mediate between contextual approaches and notions of a thin universalism. Finally, there remains the broad question of which formats can be used to integrate narrative water ethics into deliberations on which possible and desirable water futures certain governance approaches should be oriented to [131].

Funding: I acknowledge support from the German Research Foundation (Deutsche Forschungsgemeinschaft) and Open Access Publishing Fund of University of Tuebingen (Germany) as well as the Institute for Advanced Sustainability Studies e.V., Potsdam (Germany).

Acknowledgments: I thank Dietmar Mieth, Manual Rivera, and the two anonymous reviewers for their constructive feedback and ideas for improvement, Damian Harrison and Anne Boden for their editorial support, and the editors of this special issue, in particular Leila Harris, for their support, constructive feedback, and endless patience.

Conflicts of Interest: The author declares no conflict of interest. 


\section{References}

1. Aalbers, M.B. Regulated Deregulation. In The Handbook of Neoliberalism; Springer, S., Birch, K., MacLeavy, J., Eds.; Routledge: New York, NY, USA, 2016; pp. 563-573.

2. Mayntz, R. Common Goods and Governance. In Über Governance. Institutionen und Prozesse Politischer Regelung; Mayntz, R., Ed.; Campus: Frankfurt/Main, Germany; New York, NY, USA, 2009; pp. 65-78.

3. Mayntz, R. Governance im modernen Staat. In Governance-Regieren in Komplexen Regelsystemen, 2nd ed.; Benz, A., Dose, N., Eds.; VS Verlag: Wiesbaden, Germany, 2010; pp. 65-76. (In German)

4. Mayntz, R. Einleitung. In Über Governance. Institutionen und Prozesse Politischer Regelung; Campus: Frankfurt/Main, Germany, 2009; pp. 7-11. (In German)

5. Mayntz, R. New Challenges to Governance Theory. In Über Governance. Institutionen und Prozesse Politischer Regelung; Campus: Frankfurt/Main, Germany, 2009; pp. 13-28.

6. Schmidt, J.J.; Matthews, N. Global Water Challenges in Water Governance. Environments, Economies, Societies; Palgrave Macmillan: Basingstoke, UK, 2017.

7. Munck, R.; Asingwire, N.; Fagan, H.; Kabonesa, C. Water and Development: Good Governance after Neoliberalism; Zed Books: London, UK, 2015.

8. Pahl-Wostl, C. The role of governance modes and meta-governance in the transformation towards sustainable water governance. Environ. Sci. Policy 2019, 91, 6-16. [CrossRef]

9. Pahl-Wostl, C.; Toonen, T. Global Water Governance: Quo Vadis. Glob. Water Newsl. 2009, 8, 8-10.

10. Munck, R. Water, development and good governance. In Water and Development: Good Governance after Neoliberalism; Munck, R., Asingwire, N., Fagan, H., Kabonesa, C., Eds.; Zed Books: London, UK, 2015; pp. 11-29.

11. Meisch, S. The Need for a Value-Reflexive Governance in the Anthropocene. In The Global Water System in the Anthropocene: Challenges for Science and Governance; Bhaduri, A., Bogardi, J., Leentvaar, J., Marx, S., Eds.; Springer: Cham, Switzerland, 2014; pp. 427-437.

12. Perreault, T. What kind of governance for what kind of equity? Towards a theorization of justice in water governance. Water Int. 2014, 39, 233-245. [CrossRef]

13. Phillips, K.; Roberts, L. Introduction: A new era for human-water relationships. In Water, Creativity and Meaning: Multidisciplinary Understandings of Human-Water Relationships; Roberts, L., Phillips, K., Eds.; Routledge: Abingdon, UK, 2019; pp. 1-20.

14. Roberts, L.; Phillips, K. Water, Creativity and Meaning. Multidisciplinary Understandings of Human-Water Relationships; Routledge: Abingdon, UK, 2019.

15. Ingram, H. Beyond universal remedies for good water governance: A political and contextual approach. In Water for Food in a Changing World; Garrido, A., Ingram, H., Eds.; Routledge: London, UK; New York, NY, USA, 2011; pp. 241-261.

16. Böhme, H. Umriß einer Kulturgeschichte des Wassers. Eine Einleitung. In Kulturgeschichte des Wassers; Böhme, H., Ed.; Suhrkamp: Frankfurt/Main, Germany, 1988; pp. 7-42. (In German)

17. Wilder, M.; Ingram, H. Knowing Equity When We See It: Water Equity in Contemporary Global Contexts. In The Oxford Handbook of Water Politics and Policy; Conca, K., Weinthal, E., Eds.; Oxford University Press: Oxford, UK, 2016.

18. Leese, M.; Meisch, S. Securitising sustainability? Questioning the 'water, energy and food-security nexus'. Water Altern. 2015, 8, 695-709.

19. Meisch, S. What is water ethics and to what end do we study it? Lessons for the Water Ethics Charter. In Global Water Ethics. Towards a Global Ethics Charter; Ziegler, R., Groenfeldt, D., Eds.; Routledge: London, UK, 2017; pp. 37-56.

20. Meisch, S. Knowing one's food-Making food a public issue. In Know Your Food: Food Ethics and Innovation; Dumitras, D.E.J., Ionel, M., Aerts, S., Eds.; Wageningen Academic Publishers: Wageningen, the Netherlands, 2015; pp. 306-311.

21. Linton, J. Modern water and its discontents: A history of hydrosocial renewal. Wiley Interdiscip. Rev. Water 2014, 1, 111-120. [CrossRef]

22. Linton, J.; Budds, J. The hydrosocial cycle: Defining and mobilizing a relational-dialectical approach to water. Geoforum 2014, 57, 170-180. [CrossRef] 
23. Swyngedouw, E. The Political Economy and Political Ecology of the Hydro-Social Cycle. J. Contemp. Water Res. Educ. 2009, 142, 56-60. [CrossRef]

24. Orlove, B.; Caton, S.C. Water Sustainability: Anthropological Approaches and Prospects. Annu. Rev. Anthropol. 2010, 39, 401-415. [CrossRef]

25. Allouche, J.; Middleton, C.; Gyawali, D. Technical Veil, Hidden Politics: Interrogating the Power Linkages behind the Nexus. Water Altern. 2015, 8, 610-626.

26. Menga, F.; Swyngedouw, E. States of Water. In States of Water; Menga, F., Swyngedouw, E., Eds.; Routledge: Abingdon, UK, 2018; pp. 1-18.

27. Swyngedouw, E. UN Water Report 2012: Depoliticizing Water. Dev. Chang. 2013, 44, 823-835. [CrossRef]

28. Yates, J.S.; Harris, L.M.; Wilson, N.J. Multiple ontologies of water: Politics, conflict and implications for governance. Environ. Plan. D Soc. Space 2017, 35, 797-815. [CrossRef]

29. Hamlin, C. 'Waters' or 'Water'?-Master narratives in water history and their implications for contemporary water policy. Water Policy 2000, 2, 313-325. [CrossRef]

30. Feitelson, E. What is water? A normative perspective. Water Policy 2012, 14, 52-64. [CrossRef]

31. Feitelson, E.; Chenoweth, J. Water poverty: Towards a meaningful indicator. Water Policy 2002, 4, $263-281$. [CrossRef]

32. Meisch, S. A fair distribution in the Anthropocene: A normative conception of sustainable development. In Environmental Politics and Governance in the Anthropocene. Institutions and Legitimacy in a Complex World; Pattberg, P., Zelli, F., Eds.; Routledge: London, UK, 2016; pp. 62-78.

33. Mirosa, O.; Harris, L.M. Human Right to Water: Contemporary Challenges and Contours of a Global Debate. Antipode 2012, 44, 932-949. [CrossRef]

34. Doorn, N. Water and Justice: Towards an Ethics of Water Governance. Public Reason 2013, 5, 97-114.

35. Mieth, D. Sozialethik. Handbuch Ethik; Düwell, M., Hübenthal, C., Werner, M.H., Eds.; Metzler: Stuttgart, Germany, 2011; pp. 517-520. (In German)

36. Tugendhat, E. Vorlesungen über Ethik; Suhrkamp: Frankfurt/Main, Germany, 1993. (In German)

37. Swyngedouw, E. Depoliticization ('The Political'). In Degrowth: A Vocabulary for a New Era; D'Alisa, G., Demaria, F., Kallis, G., Eds.; Routledge: London, UK, 2015; pp. 90-93.

38. Wilson, J.; Swyngedouw, E. Introduction: Seeds of Dystopia: Post-Politics and the Return of the Political. In The Post-Political and Its Discontents: Spaces of Depoliticization, Spectres of Radical Politics; Wilson, J., Swyngedouw, E., Eds.; Edinburgh University Press: Edinburgh, UK, 2014; pp. 1-22.

39. Mesch, W. theôrein/theôria. In Wörterbuch der antiken Philosophie; Horn, C., Rapp, C., Eds.; Beck: München, Germany, 2008; pp. 436-437. (In German)

40. Abend, G. The Meaning of 'Theory'. Sociol. Theor. 2008, 26, 173-199. [CrossRef]

41. Lumpe, A. Kontemplation. In Reallexikon für Antike und Christentum; Schöllgen, G., Brakmann, H., Engemann, J., Fuhrer, T., Hoheisel, K., Löhr, W., Speyer, W., Thraede, K., Eds.; Anton Hiersemann: Stuttgart, Germany, 2006; pp. 486-498. (In German)

42. Blumenberg, H. Quellen, Ströme, Eisberge. Beobachtungen an Metaphern; Suhrkamp: Berlin, Germany, 2012. (In German)

43. Mieth, D. Rationalität und Narrative Ethik. Eine Erweiterung der rationalen Zugänge in der Ethik. In Zugänge zur Rationalität der Zukunft; Karafyllis, N.C., Schmidt, J.C., Eds.; Metzler: Stuttgart, Germany, 2002; pp. 277-302. (In German)

44. Mieth, D. Moral und Erfahrung I. Grundlagen einer theologisch-ethischen Hermeneutik; Herder: Freiburg/Breigau, Germany, 1999. (In German)

45. Gewirth, A. Self-fulfillment; Princeton University Press: Princeton, NJ, USA, 1998.

46. Haker, H. Narrative Ethik. Zeitschrift für Didaktik der Philosophie und Ethik 2010, 2, 74-83. (In German)

47. Haker, H. Narrative Bioethics. In Bioethics in Cultural Contexts: Reflections on Methods and Finitude; Rehmann-Sutter, C., Düwell, M., Mieth, D., Eds.; Springer Netherlands: Dordrecht, the Netherlands, 2006; pp. 353-376.

48. Mieth, D. Erzählen und Moral. Narrativität im Spannungsfeld von Ethik und Ästhetik; Attempto: Tübingen, Germany, 2000. (In German)

49. Haker, H. Moralische Identität. Literarische Lebensgeschichten als Medium ethischer Reflexion. Mit einer Interpretation der Jahrestage von Uwe Johnson; Francke: Tübingen, Germany, 1999. (In German) 
50. Düwell, M. Ästhetische Erfahrung und Moral. Zur Bedeutung des Ästhetischen für die Handlungsspielräume des Menschen; Alber: Freiburg/Breigau, Germany, 2019. (In German)

51. Ammicht-Quinn, R. Über die Notwendigkeit narrativer Identitäten. Zeitschrift für Didaktik der Philosophie und Ethik 2010, 2, 126-130. (In German)

52. Ammicht-Quinn, R. Franz Kafkas und Aleksandar Tismas Strafkolonien: Ethik, Offenheit und Verbindlichkeit. In Erzählen und Moral. Narrativität im Spannungsfeld von Ethik und Ästhetik; Mieth, D., Ed.; Attempto Verlag: Tübingen, Germany, 2000; pp. 215-236. (In German)

53. Lesch, W. Hermeneutische Ethik/Narative Ethik. In Handbuch Ethik; Düwell, M., Hübenthal, C., Werner, M.H., Eds.; Metzler: Stuttgart, Germany, 2011; pp. 231-242. (In German)

54. Düwell, M. Bioethics: Methods, Theories, Domains; Routledge: London, UK, 2013.

55. Mayntz, R. Nachhaltige Entwicklung und Governance-Neue theoretische Anforderungen. In Nord-SüdBeziehungen im Umbruch. Neue Perspektiven auf Staat und Demokratie in der Weltpolitik; Burchardt, H.-J., Ed.; Campus: Frankfurt/Main, Germany, 2009; pp. 163-181. (In German)

56. Ingram, M.; Ingram, H.; Lejano, R. What's the story? Creating and sustaining environmental networks. Environ. Politics 2014, 23, 984-1002. [CrossRef]

57. Lejano, R.; Ingram, M.; Ingram, H. The Power of Narrative in Environmental Networks; MIT Press: Cambridge, MA, USA; London, UK, 2013.

58. Heise, U.K. The Hitchhiker's Guide to Ecocriticism. PMLA 2006, 121, 503-516. [CrossRef]

59. Dietrich, J. Grundzüge einer Ethik der Ethik. In Autonomie durch Verantwortung: Impulse für die Ethik in den Wissenschaften; Berendes, J., Ed.; Mentis: Paderborn, Germany, 2007; pp. 111-146. (In German)

60. Benessia, A.; Funtowicz, S. Sustainability and technoscience: What do we want to sustain and for whom? Int. J. Sustain. Dev. 2015, 18, 329-348. [CrossRef]

61. Benessia, A.; Funtowicz, S.; Bradshaw, G.; Ferri, F.; Ráez-Luna, E.; Medina, C. Hybridizing sustainability: Towards a new praxis for the present human predicament. Sustain. Sci. 2012, 7, 75-89. [CrossRef]

62. Benessia, A.; Funtowicz, S. Never Late, Never Lost, Never Unprepared. In The Rightful Place of Science: Science on the Verge; Benessia, A., Funtowicz, S., Giampietro, M., Guimarães Pereira, Â., Ravetz, J., Saltelli, A., Strand, R., van der Sluijs, J., Eds.; Consortium for Science, Policy \& Outcomes Tempe: Washington, DC, USA, 2016; pp. 71-113.

63. Guimarães Pereira, Â.; Funtowicz, S. Science, Philosophy and Sustainability: The End of the Cartesian Dream; Routledge: London, UK; New York, USA, 2015.

64. Offe, C. Governance: An “Empty Signifier"? Constellations 2009, 16, 550-562. [CrossRef]

65. Streeck, W. Von der gesteuerten Demokratie zum selbststeuernden Kapitalismus: Die Sozialwissenschaften in der Liberalisierung. WestEnd Neue Zeitschrift für Sozialforschung 2009, 6, 13-33. (In German)

66. Feldman, D.L.; Ingram, H. Multiple Ways of Knowing Water Resources: Enhancing the Status of Water Ethics. St. Clara J. Int. Law 2009, 7, 1.

67. Grundmann, R. Climate change as a wicked social problem. Nat. Geosci. 2016, 9, 562-563. [CrossRef]

68. Bakker, K. Water: Political, biopolitical, material. Soc. Stud. Sci. 2012, 42, 616-623. [CrossRef]

69. Böhme, H. Kulturgeschichte des Wassers; Suhrkamp: Frankfurt/Main, Germany, 1988. (In German)

70. Strang, V. The Meaning of Water; Berg Publishers: Oxford, UK, 2004.

71. Illich, I. $\mathrm{H}_{2} \mathrm{O}$ and the Waters of Forgetfulness: Reflections on the Historicity of Stuff; Dallas Institute of Humanities \& Culture: Dallas, TX, USA, 1985.

72. Swyngedouw, E. Dispossessing $\mathrm{H}_{2} \mathrm{O}$ : The contested terrain of water privatization. Capital. Nat. Soc. 2005, 16, 81-98. [CrossRef]

73. Swyngedouw, E. Privatising $\mathrm{H}_{2} \mathrm{O}$. Turning Local Waters Into Global Money. J. Entwickl. 2003, 19, 10-33. [CrossRef]

74. Bakker, K. From State to Market?: Water Mercantilización in Spain. Environ. Plan. A Econ. Space 2002, 34, 767-790. [CrossRef]

75. Schmidt, J.J.; Matthews, N. From state to system: Financialization and the water-energy-food-climate nexus. Geoforum 2018, 91, 151-159. [CrossRef]

76. Kooy, M.; Bakker, K. Technologies of Government: Constituting Subjectivities, Spaces, and Infrastructures in Colonial and Contemporary Jakarta. Int. J. Urban Reg. Res. 2008, 32, 375-391. [CrossRef]

77. Swyngedouw, E. Liquid Power: Contested Hydro-Modernities in 20th Century Spain; MIT Press: Cambridge, MA, USA, 2015. 
78. Chandler, D. Beyond neoliberalism: Resilience, the new art of governing complexity. Resilience 2014, 2, 47-63. [CrossRef]

79. Reid, J. Interrogating the Neoliberal Biopolitics of the Sustainable Development-Resilience Nexus. Int. Political Sociol. 2013, 7, 353-367. [CrossRef]

80. Mayntz, R. Governance im modernen Staat. In Governance-Regieren in Komplexen Regelsystemen. Eine Einführung; Benz, A., Ed.; VS Verlag für Sozialwissenschaften: Wiesbaden, Germany, 2010; pp. 37-48. (In German)

81. Mayntz, R. Zur Selektivität der steuerungstheoretischen Perspektive. In Über Governance. Institutionen und Prozesse Politischer Regelung; Campus: Frankfurt/Main, Germany, 2009; pp. 29-40. (In German)

82. Immergut, E.M. Democratic Theory and Policy Analysis: Four Models of "Policy, Politics and Choice". der moderne staat—dms: Zeitschrift für Public Policy, Recht und Management 2011, 1, 69-86. (In German)

83. Wiegleb, V.; Bruns, A. What Is Driving the Water-Energy-Food Nexus? Discourses, Knowledge, and Politics of an Emerging Resource Governance Concept. Front. Environ. Sci. 2018, 6, 1-15. [CrossRef]

84. Swyngedouw, E. Wasser, Geld und Macht. In Wasser. Die Kommerzialisierung eines öffentlichen Gutes; Deckwirth, C., Huesker, F., Naumann, M., Otto, B., Pflug, T., Terhorst, P., Weidenberg, K., Eds.; Karl Dietz: Berlin, Germany, 2008. (In German)

85. Funtowicz, S.O.; Ravetz, J.R. Science for the post-normal age. Futures 1993, 25, 739-755. [CrossRef]

86. Bremer, S.; Meisch, S. Co-production in climate change research: Reviewing different perspectives. Wiley Interdiscip. Rev. Clim. Chang. 2017, 8, e482. [CrossRef]

87. Ricken, F. Allgemeine Ethik, 5th ed.; Kohlhammer: Stuttgart, Germany, 2013. (In German)

88. Schmidt, J.J.; Peppard, C.Z. Water ethics on a human-dominated planet: Rationality, context and values in global governance. Wiley Interdiscip. Rev. Water 2014, 1, 533-547. [CrossRef]

89. Grunwald, A. Water ethics-Orientation for water conflicts as part of inter- and transdisciplinary deliberation. In Society-Water-Technology. A Critical Appraisal of Major Water Engineering Projects; Reinhard, F., Hüttl, R., Bens, O., Bismuth, C., Hoechstetter, S., Eds.; Springer: Cham, Switzerland, 2016; pp. 11-29.

90. Groenfeldt, D.; Schmidt, J.J. Ethics and Water Governance. Ecol. Soc. 2013, 18, 1-14. [CrossRef]

91. Nussbaum, M. Creating Capabilities: The Human Development Approach; Belknap Press: Cambridge, MA, USA, 2013.

92. Sandel, M. Justice: What's the Right Thing to Do? Farrar, Straus and Giroux: New York, NY, USA, 2010.

93. Rivera, M.; Nanz, P. Erzählend handeln, Handeln erzählen: Fragen an Narrative Nachhaltiger Entwicklung. In Leben im Anthropozän: Christliche Perspektiven für eine Kultur der Nachhaltigkeit; Bertelmann, B., Heidel, K., Eds.; Oekom verlag: München, Germany, 2018; pp. 137-148. (In German)

94. Espinosa, C.; Pregernig, M.; Fischer, C. Narrative und Diskurse in der Umweltpolitik: Möglichkeiten und Grenzen ihrer strategischen Nutzung; German Environment Agency (Umweltbundesamt - UBA): Dessau-Roßlau, Germany, 2017. (In German)

95. Taylor, C. The Language Animal: The Full Shape of the Human Linguistic Capacity; Belknap Press: Cambridge, MA, USA; London, UK, 2016.

96. Hofer, S.; Meisch, S. Extremwetter: Konstellationen des Klimawandels in der Literatur der frühen Neuzeit. In Extremwetter: Konstellationen des Klimawandels in der Literatur der frühen Neuzeit, 1st ed.; Meisch, S., Hofer, S., Eds.; Nomos: Baden-Baden, Germany, 2018; pp. 9-68. (In German)

97. Weimar, K. Lesen: zu sich selbst sprechen in fremdem Namen. In Literaturwissenschaft. Einführung in ein Sprachspiel; Renner-Henke, U., Bosse, H., Eds.; Rombach: Freiburg, Germany, 1999; pp. 49-62. (In German)

98. Mieth, D. Norm und Erfahrung: Die Relevanz der Erfahrung für die ethische Theorie und die sittliche Praxis. Zeitschrift Für Evangelische Ethik 1993, 37, 33-45. (In German) [CrossRef]

99. O'Neill, O. Applied Ethics: Naturalism, Normativity and Public Policy. J. Appl. Philos. 2009, 26, $219-230$. [CrossRef]

100. Mieth, D. Was wollen wir können? Ethik im Zeitalter der Biotechnik; Herder: Freiburg/Breigau, Germany, 2006. (In German)

101. Potthast, T. Ethics in the Sciences beyond Hume, Moore and Weber: Taking Epistemic-Moral Hybrids Seriously. In Ethics of Science in the Research for Sustainable Development, 1st ed.; Meisch, S., Lundershausen, J., Bossert, L., Rockoff, M., Eds.; Nomos: Baden-Baden, Germany, 2015; pp. 129-152. 
102. Dietrich, J. Was ist ethische Kompetenz? Ein Philosophischer Versuch einer Systematisierung und Konkretion. In Wertloses Wissen? Fachunterricht als Ort ethischer Reflexion; Ammicht Quinn, R., Badura-Lotter, G., Knödler-Pasch, M., Mildenberger, G., Rampp, B., Eds.; Klinkhardt: Bad Heilbrunn, Germany, 2007; pp. 31-51. (In German)

103. Arendt, H. The Human Condition; University of Chicago Press: Chicago, IL, USA, 1998.

104. Goodbody, A.; Wanning, B. Wasser Kultur Ökologie; Beiträge zum Wandel im Umgang mit dem Wasser und zu seiner literarischen Imagination; v\&r unipress: Göttingen, Germany, 2008. (In German)

105. Féaux de la Croix, J. Iconic Places in Central Asia. The Moral Geography of Dams, Pastures and Holy Sites; Transcript: Bielefeld, Germany, 2017.

106. Gooley, T. How to Read Water: Clues and Patterns from Puddles to the Sea; Hodder \& Stoughton: London, UK, 2017.

107. Wallace, D.F. This Is Water: Some Thoughts, Delivered on a Significant Occasion, about Living a Compassionate Life; Little, Brown and Company: New York, NY, USA, 2009.

108. Bakewell, L.; Liguori, A.; Wilson, M. From Gallura to the Fens: Communities performing stories of water. In Water, Creativity and Meaning. Multidisciplinary Understandings of Human-Water Relationships; Roberts, L., Phillips, K., Eds.; Routledge: London, UK, 2018; pp. 70-84.

109. Giampietro, M.; Aria, M.; Cabello, V.; Cadillo Benalcazar, J.; D’Ambrosio, A.; de La Fuente, J.A.; Di Felice, L.; Iorio, C.; Kovacic, Z.; Krol, M.; et al. Report on Nexus Security using Quantitative Story-Telling. Technical Report. 2017. Available online: https://www.researchgate.net/publication/324029732_Report_on_Nexus_ Security_using_Quantitative_Story-Telling(accessed on 27 March 2019).

110. Ravetz, J. Scientific Knowledge and Its Social Problems; Transaction Publishers: New Brunswick, NJ, USA; London, UK, 1971.

111. Saltelli, A.; Giampietro, M. What is wrong with evidence based policy, and how can it be improved? Futures 2017, 91, 62-71. [CrossRef]

112. Strand, R. Post-normal Science. In Routledge Handbook of Ecological Economics: Nature and Society; Spash, C.L., Ed.; Routledge: London, UK, 2017; pp. 288-297.

113. MAGIC. Moving Towards Adaptive Governance in Complexity: Informing Nexus Security. Available online: http:/ / magic-nexus.eu/ (accessed on 1 December 2018).

114. Giampietro, M. Perception and Representation of the Resource Nexus at the Interface between Society and the Natural Environment. Sustainability 2018, 10, 2545. [CrossRef]

115. Madrid López, C.; Giampietro, M. Water grammar. In Resource Accounting for Sustainability Assessment: The Nexus between Energy, Food, Water and Land Use; Giampietro, M., Aspinall, R.J., Ramos-Martin, J., Bukkens, S.G.F., Eds.; Routledge: London, UK, 2014; pp. 116-134.

116. Deakin, R. Waterlog: A Swimmer's Journey Through Britain; Random House: London, UK, 2000.

117. Macfarlane, R. The Old Ways. A Journey on Foot; Penguin: London, UK, 2012.

118. Meisch, S. And all at once the clouds descend, Shed tears that never seem to end: Looking from the early modern age at water in the Anthropocene. In Water, Creativity and Meaning. Multidisciplinary Understandings of Human-Water Relationships; Roberts, L., Phillips, K., Eds.; Routledge: Abingdon, UK, 2019; pp. 172-185.

119. Hofer, S. Jeremias Gotthelfs Die Wassernot im Emmental am 13. August 1837 als hybrides Extremwetternarrativ auf der Schwelle zwischen Kleiner Eiszeit und Anthropozän. In Extremwetter: Konstellationen des Klimawandels in der Literatur der frühen Neuzeit, 1st ed.; Meisch, S., Hofer, S., Eds.; Nomos: Baden-Baden, Germany, 2018; pp. 169-198. (In German)

120. Wikipedia. Waterwolf. Available online: https://en.wikipedia.org/wiki/Waterwolf (accessed on 12 December 2018).

121. Haarlemmermeermuseum. Pumping station Cruquius. Available online: https://www. haarlemmermeermuseum.nl/en (accessed on 1 December 2018).

122. Schmidt, J.J. Historicising the Hydrosocial Cycle. Water Altern. 2014, 7, 220-234.

123. Schmidt, J.J. Water: Abundance, Scarcity, and Security in the Age of Humanity; New York University Press: New York, NY, USA, 2017.

124. Schmidt, J.J. What is water? The history of a modern abstraction by Jamie Linton, University of British Columbia Press, Vancouver, 2010, xviii + 333 pp., paper C\$34.95 (ISBN 978-0774817028). Can. Geogr. 2011, 55, 513-514. [CrossRef]

125. Bakker, K. Good Governance in Restructuring Water Supply: A Handbook; Federation of Canadian Municipalities: Ottawa, ON, Canada, 2003. 
126. Ammicht-Quinn, R. Kulturethik. In Handbuch Ethik; Düwell, M., Hübenthal, C., Werner, M.H., Eds.; Metzler: Stuttgart, Germany, 2002; pp. 258-263. (In German)

127. Mihai, M.; McNay, L.; Marchart, O.; Norval, A.; Paipais, V.; Prozorov, S.; Thaler, M. Democracy, critique and the ontological turn. Contemp. Polit. Theory 2017, 16, 501-531. [CrossRef]

128. Haker, H. The Fragility of the Moral Self. Harv. Theol. Rev. 2004, 97, 359-381. [CrossRef]

129. Groenfeldt, D. An Overview of Water Ethics. Water Resour. IMPACT 2018, 20, 6. Available online: https: / / test.awra.org/impact/2-Mar2018IMPACTSample.pdf (accessed on 26 March 2019).

130. Kowarsch, M. Diversity of water ethics-A literature review; 2nd working paper prepared for the research project "Sustainable Water Management in a Globalized World", funded by Germany's Federal Ministry of Education and Research, published online. 2011. Available online: http:/ / www.hfph.de/forschung/institute/gesellschaftspolitik/forschung/wirtschaft-und-ressourcen/ wassermanagement/2nd-working-paper-sept-2011.pdf (accessed on 2 February 2015).

131. Meisch, S. Water ethics-Lessons from post-normal science. In Professionals in Food Chains; Springer, S., Grimm, H., Eds.; Wageningen Academic Publishers: Wageningen, the Netherlands, 2018; pp. 459-464.

(C) 2019 by the author. Licensee MDPI, Basel, Switzerland. This article is an open access article distributed under the terms and conditions of the Creative Commons Attribution (CC BY) license (http://creativecommons.org/licenses/by/4.0/). 